\title{
Publisher Correction: Loss of POMC-mediated antinociception contributes to painful diabetic neuropathy
}

Divija Deshpande, Nitin Agarwal, Thomas Fleming, Claire Gaveriaux-Ruff(D, Christoph S. N. Klose (1), Anke Tappe-Theodor (D, Rohini Kuner (1) \& Peter Nawroth

Correction to: Nature Communications https://doi.org/10.1038/s41467-020-20677-0, published online 18 January 2021.

The original version of the Peer Review File associated with this Article was updated shortly after publication to redact unpublished data.

Published online: 08 February 2021

\footnotetext{
(c) Open Access This article is licensed under a Creative Commons Attribution 4.0 International License, which permits use, sharing, adaptation, distribution and reproduction in any medium or format, as long as you give appropriate credit to the original author(s) and the source, provide a link to the Creative Commons license, and indicate if changes were made. The images or other third party material in this article are included in the article's Creative Commons license, unless indicated otherwise in a credit line to the material. If material is not included in the article's Creative Commons license and your intended use is not permitted by statutory regulation or exceeds the permitted use, you will need to obtain permission directly from the copyright holder. To view a copy of this license, visit http://creativecommons.org/licenses/by/4.0/.
}

(C) The Author(s) 2021 